\title{
Serum 8-hydroxy-2-deoxyguanosine as a marker of DNA oxidative damage in horses with recurrent airway obstruction
}

\author{
Artur Niedzwiedz ${ }^{1 *}$ (D, Hieronim Borowicz ${ }^{1}$, Lidia Januszewska², Iwona Markiewicz-Gorka² \\ and Zbigniew Jaworski ${ }^{3}$
}

\begin{abstract}
Background: It has been reported that equine recurrent airway obstruction (RAO) is a state of oxidative stress. Oxidant-antioxidant imbalance is known to increase the conversion of deoxyguanosine to 8-hydroxy-2-deoxyguanosine (8-OHdG) in DNA. 8-OHdG can easily be measured using ELISA tests in serum or urine samples. In this study, we analysed serum 8-OHdG levels in horses with recurrent airway obstruction and in healthy controls.

Results: The study material consisted of seven healthy horses and seven horses with symptomatic RAO. All horses were exposed to moldy hay and straw for $48 \mathrm{~h}$ to induce clinical exacerbation of RAO. The serum 8-OHdG levels were determined using the ELISA Highly Sensitive 8-OHdG kit. The difference between the levels of 8-OHdG in healthy and RAO-affected horses was significant. The median level of $8-O H d G$ was $0.044 \mathrm{ng} / \mathrm{ml}$ in the healthy controls versus $0.498 \mathrm{ng} / \mathrm{ml}$ in RAO horses $(P=0.0021)$.

Conclusions: The results of the study strongly suggest that DNA damage coexists in the course of equine RAO. We therefore propose that future research should aim at the development of new drugs that target pro-inflammatory molecules, since DNA damage appears to be the result of chronic inflammation.
\end{abstract}

Keywords: Heaves, Horse, DNA damage, Oxidative damage, RAO, Oxidative stress

\section{Findings}

Recurrent airway obstruction (RAO) also known as heaves, is an allergic, inflammatory and obstructive airway disease that usually affects older horses and shares many characteristic features with human asthma $[1,2]$.

Several studies have clearly shown that oxidative stress in the course of equine heaves results from an inflammatory response [3-7]. Moreover, reactive oxygen species (ROS) can generate severe oxidative damage in nucleic acids, such as strand breaks and base oxidations [8]. 8-hydroxy-2-deoxyguanosine (8-OHdG) is one of the best-known oxidation products as it has a high premutagenic potential and is easy to analyze $[9,10]$. To date, the

\footnotetext{
*Correspondence: artur.niedzwiedz@up.wroc.pl

${ }^{1}$ Department of Internal Diseases with Clinic for Horses, Dogs and Cats, Wroclaw University of Environmental and Life Sciences, pl. Grunwaldzki 47, 50-366 Wrocław, Poland

Full list of author information is available at the end of the article
}

level of 8-OHdG has not been reported in the course of equine RAO. Thus, in this study, equine serum levels of 8-OHdG were determined.

All animal experimental procedures in this study were performed with the approval of the 2nd Local Ethics Committee on Animal Experimentation in Wrocław (permission No 1/2012).

Seven Polish Konik horses (five geldings and two mares, median age 8 , range $5-13,6$ horses were $<10$ years old) that had no symptoms of airway disease were used as controls. Seven Polish Konik horses with a history of RAO were included in the study group (four geldings and three mares, median age 9, range 7-14, 4 horses were $<10$ years old). Samples from these horses have been included in previous publications; therefore some data, i.e. clinical assessment and bronchoalveolar lavage fluid (BALF) cytology are duplicated [11, 12].

(c) 2016 Niedzwiedz et al. This article is distributed under the terms of the Creative Commons Attribution 4.0 International License (http://creativecommons.org/licenses/by/4.0/), which permits unrestricted use, distribution, and reproduction in any medium, provided you give appropriate credit to the original author(s) and the source, provide a link to the Creative Commons license, and indicate if changes were made. The Creative Commons Public Domain Dedication waiver (http://creativecommons.org/ publicdomain/zero/1.0/) applies to the data made available in this article, unless otherwise stated. 
All the horses were enrolled in the study based on their medical history, a thorough clinical examination, endoscopy of the airways and the results of a bronchoalveolar lavage fluid cytology. An acute crisis of heaves in RAOaffected horses was induced by placing the horses in a poorly ventilated stable, bedding them on straw and feeding them hay with visible mold growth for $48 \mathrm{~h}$ prior to the examination. Airway endoscopy and bronchoalveolar lavage were performed in all the animals using previously described methods $[11,12]$. For cytology, sample aliquots were cytospinned at $300 \times g$ for $10 \mathrm{~min}$ (Allegra $\mathrm{x}-22$ cytospin, Beckman Coulter, Brea, USA). Smears were prepared and stained with Wright's stain. A 400-cell leukocyte differential count $(\times 1000$ magnification $)$ was performed wherein epithelial cells were not taken into account [13].

Thawed serum samples were used to determine the level of 8-OHdG by a commercial ELISA kit (Highly Sensitive 8-OHdG Check ELISA; Fukuroi, Shizuoka, Japan). First, the serum samples were passed through $0.5 \mathrm{ml}$ $10 \mathrm{~K}$ Amicon Ultra Centrifugal Filters (Merck Millipore, Darmstadt, Germany) to remove any large-molecularweight substances. Then, $50 \mu \mathrm{l}$ of a primary monoclonal antibody and $50 \mu \mathrm{l}$ of a sample/standard were added to the microtiter plate wells, which were pre-coated with the 8-OHdG. The plates were sealed tightly and incubated at $37^{\circ} \mathrm{C}$ for $1 \mathrm{~h}$ in the dark. After washing with $250 \mu \mathrm{l}$ of phosphate-buffered saline (PBS), $100 \mu \mathrm{L}$ of secondary antibody conjugated with horse radish peroxidase was added to each well and incubated at $37^{\circ} \mathrm{C}$ in the dark for $1 \mathrm{~h}$. Following a second washing step, $100 \mu \mathrm{l}$ of the enzyme substrate was added to each well and the reaction was stopped after $15 \mathrm{~min}$ by adding $100 \mu \mathrm{l}$ of $1 \mathrm{M}$ phosphoric acid. Absorbance readings were taken $3 \mathrm{~min}$ later with a spectrophotometer operating at $450 \mathrm{~nm}$. The results were expressed as $\mathrm{ng} / \mathrm{ml}$ serum.

Data are presented as median values and 25th and 75th percentiles. The nonparametric U Mann-Whitney test was used to analyze data using STATISTICA v. 10.0 software (StatSoft, Tulsa, OK, USA). $P<0.05$ was considered statistically significant.

The results of the BALF analysis, clinical assessment and arterial blood gasometry are shown in Table 1. BALF median recovery in the control horses was 56.6 and $43.6 \%$ in the RAO-affected horses. Statistical analysis demonstrated a significant effect of exposure to moldy hay and straw for $48 \mathrm{~h}$ on the percentage of BALF cells in the horses with heaves compared to the controls.

8-hydroxy-2-deoxyguanosine was detected in all serum samples. There was a significant difference in the levels of 8-OHdG between healthy and RAO-affected horses $(P=0.0021)$. The median level of 8-OHdG was $0.044 \mathrm{ng} /$ $\mathrm{ml}$ in the healthy controls versus $0.498 \mathrm{ng} / \mathrm{ml}$ in $\mathrm{RAO}$ horses (Fig. 1).
Table 1 Results of bronchoalveolar lavage fluid cytology, clinical assessment and blood gas analysis in healthy horses and recurrent airway obstruction (RAO)—affected horses sampled after challenge to moldy hay and straw

\begin{tabular}{lcc}
\hline & Healthy $(\mathbf{n}=\mathbf{7})$ & RAO-affected $(\mathbf{n}=\mathbf{7})$ \\
\hline Clinical score $^{\mathrm{a}}$ & $2.0(2$ and 2$)$ & $6(5$ and 6$)$ \\
PaO2 $(\mathrm{mmHg})^{\mathrm{a}}$ & $96(91$ and 108$)$ & $91(85$ and 107$)$ \\
PaCO2 $(\mathrm{mmHg})$ & $45(43$ and 46$)$ & $45.5(44$ and 50$)$ \\
BALF neutrophils $(\%)^{\mathrm{a}}$ & $5.1(4.1$ and 5.3$)$ & $59.8(51.3$ and 64.8$)$ \\
BALF lymphocytes $(\%)^{\mathrm{a}}$ & $41(38.5$ and 45.9$)$ & $38.1(34.8$ and 41.1$)$ \\
BALF macrophages $(\%)^{\mathrm{a}}$ & $55.8(49.8$ and 59.1$)$ & $32.8(25.9$ and 35.7$)$ \\
BALF eosinophils $(\%)^{\mathrm{a}}$ & $0.4(0.2$ and 0.5) & $0(0$ and 0) \\
BALF mast cells $(\%)$ & $0.1(0$ and 0.3$)$ & $0(0$ and 0$)$
\end{tabular}

Values are expressed as median and 25th and 75 th percentiles. This table has been published previously $[11,12]$

a Differences statistically significant $(P<0.05)$

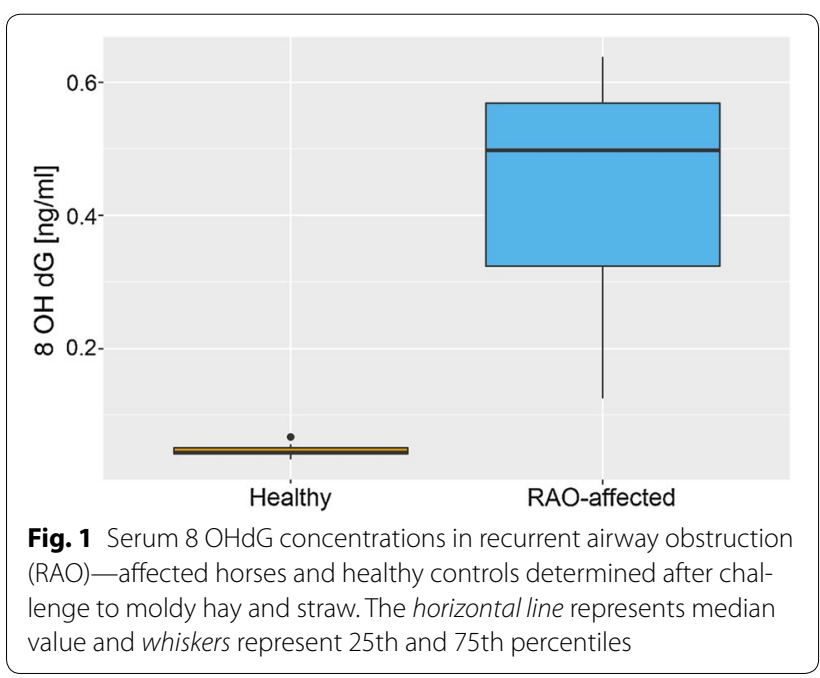

It has recently been confirmed that equine RAO is accompanied by oxidative stress [14]. The generation of ROS through a number of endogenous mechanisms, including activation of redox-sensitive transcription factors and pro-inflammatory signaling pathways, is critical to the inflammatory response. At the same time, an inadequate antioxidant defense may lead to a chronic and a more pronounced inflammatory response. An exacerbation of RAO is manifested by airway inflammation, including an influx of circulating white blood cells (predominantly non-degenerate neutrophils) into the bronchial lumen [1]. When activated, leukocytes release many pro-inflammatory mediators that amplify the inflammation [15] and leads to cell damage [16].

Another mechanism that may underlie oxidative stress in the course of RAO is hypoxia, which typically develops 
in horses during disease exacerbation [17, 18]. Equine heaves causes inadequate oxygen supply to the cells and tissues and leads to overexpression of the hypoxiainducible factor (HIF), which is a major regulator of energy homeostasis and cellular adaption to hypoxia. The expression of the HIF-1 alpha subunit gene (HIF1A) is upregulated in myeloid cells of horses with RAO [17]. An in vitro study also showed a significantly increased expression of the HIF1A in stimulated peripheral blood mononuclear cells (PBMCs) of RAO-affected horses [18]. HIF1A has a central role in the response to hypoxia. A possible cause of the oxidative stress is mediated by the release of the kappa B nuclear factor (NFkB), a transcriptional factor that triggers the inflammatory process [19]. Another explanation of oxidative stress in equine RAO may be an increased anaerobic glycolysis and a loss of electrons from the mitochondrial electron transport chain [20].

DNA and RNA can be damaged by ROS, which are generated in cellular metabolic pathways as a response to exposure to factors, such as UV light or heat. Highly ROS may cause DNA damage, leading to hydroxylation of nucleic acids [21]. Among the multiple products of nucleoside oxidation, 8-hydroxy-2-deoxyguanosine (8-OHdG) and 8-hydroxyguanosine (8-OHG) are two of the most prominent and best-characterized compounds [8-10].

This study confirms an elevated level of serum 8-OHdG in RAO-affected horses, that may be associated with increased level of DNA damage (Fig. 1). To date, no studies assessing the levels of DNA-oxidative damage markers in horses have been reported. However, our results are consistent with other studies where significant increased levels of markers of DNA-oxidative damage in COPD or asthmatic patients were found [22-24].

Despite differences in the results obtained from humans and horses, it is still of concern that RAOaffected horses have almost 10 times higher levels of 8-OHdG compared to healthy horses. It is not clear from the present research how RAO-affected horses developed higher levels of oxidative DNA damage. Recurrent airway obstruction contributes to oxidative damage through an increase in the production of, and exposure to ROS [14]. $\mathrm{RAO}$ is associated with an activation of innate immune responses, the promotion of inflammation, and increased vulnerability to latent infection. Activated phagocytes are significant sources of ROS as a part of the cytotoxic host response against invading pathogens [24]. This process may underlie the phenomenon that members of the highprevalence RAO family show a low degree of intestinal parasitism $[25,26]$. However, the ability to induce specific host immune regulatory mechanisms may be partly determined by host genetics. Horses that are genetically susceptible to allergic disease may be more likely to develop allergic responses to nematodes. Based on the above mentioned mechanism, they may be genetically more resistant to parasite infection. Another possibility is that equine RAO affects the repair of damaged DNA. A reduction in the repair process could increase the measured levels of oxidative damage products by allowing their persistence rather than increasing their formation. Future research including simultaneous measurements of innate immune activation, DNA damage and DNA repair, may enhance our knowledge on the pathophysiology of this process.

The demonstration of a shift in the oxidant-antioxidant balance in favor of the former suggests that augmentation of antioxidant defenses by means of therapeutic interventions may be beneficial.

In conclusion, the results strongly suggest that DNA damage coexists in the course of equine RAO. Oxidative stress and consequent DNA damage appear to be the result of chronic inflammation. Therefore, the development of new drugs that target pro-inflammatory molecules or ROS-inducers in the course of equine RAO should be attempted. Moreover, a shift in the oxidantantioxidant balance in favor of the former suggests that augmentation of antioxidant defenses by means of therapeutic interventions may be beneficial.

\section{Abbreviations}

8-OHdG: 8-hydroxy-2-deoxyguanosine; BALF: bronchoalveolar lavage fluid; HIF: hypoxia-inducible factor; NFkB: kappa B nuclear factor; $\mathrm{PaCO}_{2}$ : partial pressure of carbon dioxide; $\mathrm{PaO}_{2}$ : partial pressure of oxygen; PBMCs: peripheral blood mononuclear cells; RAO: recurrent airway obstruction; ROS: reactive oxygen species.

\section{Authors' contributions}

AN designed the study, conducted the experiments, collected all samples, performed the blood and BALF analysis and wrote the manuscript. ZJ and $\mathrm{HB}$ were responsible for the animals, helped obtain the samples and write the manuscript. $L$ and IMG performed the ELISA test. All authors read and approved the final manuscript.

\section{Author details}

${ }^{1}$ Department of Internal Diseases with Clinic for Horses, Dogs and Cats, Wroclaw University of Environmental and Life Sciences, pl. Grunwaldzki 47, 50-366 Wrocław, Poland. ${ }^{2}$ Department of Hygiene, Wroclaw Medical University, J. Mikulicza-Radeckiego 7, 50-435 Wrocław, Poland. ${ }^{3}$ Department of Horse Breeding and Riding, University of Warmia and Mazury, Prawocheńskiego 2, 10-720 Olsztyn, Poland.

\section{Acknowledgements}

This research was supported by statutory research and development activity funds assigned to the Faculty of Veterinary Medicine, Wroclaw University of Environmental and Life Science Grant No. MWet/410/2014/SC.

\section{Competing interests}

The authors declare that they have no competing interests.

Received: 31 December 2015 Accepted: 20 May 2016

Published online: 07 June 2016 


\section{References}

1. Léguillette R. Recurrent airway obstruction—heaves. Vet Clin North Am Equine Pract. 2003;19:63-86.

2. Bowler RP, Crapo JD. Oxidative stress in allergic respiratory diseases. J Allergy Clin Immunol. 2002;110:349-56.

3. Deaton CM, Marlin DJ, Smith NC, Smith KC, Newton RJ, Gower SM, et al. Breath condensate hydrogen peroxide correlate with both airway cytology and epithelial lining fluid ascorbic acid concentration in the horse. Free Radic Res. 2004;38:201-8.

4. Deaton CM, Marlin DJ, Deaton L, Smith NC, Harris PA, Schroter RC, Kelly FJ. Comparison of the antioxidant status in tracheal and bronchoalveolar epithelial lining fluids in recurrent airway obstruction. Equine Vet J. 2006;38:417-22

5. Kirschvink N, Marlin D, Delvaux F, Leemans J, Clercx C, Sparkes A, Gustin P. Collection of exhaled breath condensate and analysis of hydrogen peroxide as a potential marker of lower airway inflammation in cats. Vet J. 2005; 169:385-96.

6. Art T, Kirschvink N, Smith N, Lekeux P. Indices of oxidative stress in blood and pulmonary epithelium lining fluid in horses suffering from recurrent airway obstruction. Equine Vet J. 1999:31:397-401.

7. Kirschvink N, Smith N, Fiévez L, Bougnet V, Art T, Degand G, et al. Effect of chronic airway inflammation and exercise on pulmonary and systemic antioxidant status of healthy and heaves-affected horses. Equine Vet J. 2002;34:563-71.

8. Valavanidis A, Vlachogianni T, Fiotakis C. 8-hydroxy-2'-deoxyguanosine (8-OHdG): a critical biomarker of oxidative stress and carcinogenesis. J Environ Sci Health C Environ Carcinog Ecotoxicol Rev. 2009;27:120-39.

9. Wu LL, Chiou CC, Chang PY, Wu JT. Urinary 8-OHdG: a marker of oxidative stress to DNA and a risk factor for cancer, atherosclerosis and diabetics. Clin Chim Acta. 2004;339:1-9.

10. Soini Y, Haapasaari KM, Vaarala MH, Turpeenniemi-Hujanen T, Kärjä V, Karihtala P. 8-hydroxydeguanosine and nitrotyrosine are prognostic factors in urinary bladder carcinoma. Int J Clin Exp Pathol. 2011:4:267-75.

11. Niedźwiedź A, Jaworski Z. Recurrent respiratory disorders in Polish Konik horses-clinical and laboratory findings. Bull Vet Inst Pulawy. 2014;58:93-7.

12. Wysocka B, Kluciński W. Usefulness of the assessment of discharge accumulation in the lower airways and tracheal septum thickening in the differential diagnosis of recurrent airway obstruction (RAO) and inflammatory airway disease (IAD) in the horse. Pol J Vet Sci. 2014;17:247-53.
13. Fernandez NJ, Hecker KG, Gilroy CV, Warren AL, Léguillette R. Reliability of 400-cell and 5-field leukocyte differential counts for equine bronchoalveolar lavage fluid. Vet Clin Pathol. 2013;42:92-8.

14. Niedzwiedz A, Jaworski Z. Oxidant-antioxidant status in the blood of horses with symptomatic recurrent airway obstruction (RAO). J Vet Intern Med. 2014;28:1845-52.

15. Varani J, Ward PA. Mechanisms of neutrophil-dependent and neutrophilindependent endothelial cell injury. Biol Signals. 1994;3:1-14.

16. Ricciardolo FL, Di Stefano A, Sabatini F, Folkerts G. Reactive nitrogen species in the respiratory tract. Eur J Pharmacol. 2006;533:240-52.

17. Toussaint M, Fievez L, Desmet CJ, Pirottin D, Farnir F, Bureau F, Lekeux P. Increased hypoxia-inducible factor 1 a expression in lung cells of horses with recurrent airway obstruction. BMC Vet Res. 2012;8:64.

18. Pacholewska A, Jagannathan V, Drögemüller M, Klukowska-Rötzler J, Lanz

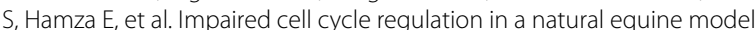
of asthma. PLoS ONE. 2015;10(8):e0136103.

19. Araneda OF, Tuesta M. Lung oxidative damage by hypoxia. Oxid Med Cell Longev. 2012:2012:856918. doi:10.1155/2012/856918.

20. Miyata T, Takizawa S, van Ypersele de Strihou C. Hypoxia. 1. Intracellular sensors for oxygen and oxidative stress: novel therapeutic targets. Am J Physiol Cell Physiol. 2011;300:C226-31.

21. Fimognari $C$. Role of oxidative RNA damage in chronic-degenerative diseases. Oxid Med Cell Longev. 2015;2015:358713. doi:10.1155/2015/358713.

22. Zeyrek D, Cakmak A, Atas A, Kocyigit A, Erel O. DNA damage in children with asthma bronchiale and its association with oxidative and antioxidative measurements. Pediatr Allergy Immunol. 2009;20:370-6.

23. Hasbal C, Aksu BY, Himmetoglu S, Dincer Y, Koc EE, Hatipoglu S, Akcay T. DNA damage and glutathione level in children with asthma bronchiale: effect of antiasthmatic therapy. Pediatr Allergy Immunol. 2010;21:e674-8.

24. Al-Afaleg NO, Al-Senaidy A, El-Ansary A. Oxidative stress and antioxidant status in Saudi asthmatic patients. Clin Biochem. 2011;44:612-7.

25. Bründler P, Frey CF, Gottstein B, Nussbaumer P, Neuhaus S, Gerber V. Lower shedding of strongylid eggs by Warmblood horses with recurrent airway obstruction compared to unrelated healthy horses. Vet J. 2011;190:e12-5.

26. Neuhaus S, Bruendler P, Frey CF, Gottstein B, Doherr MG, Gerber V. Increased parasite resistance and recurrent airway obstruction in horses of a high-prevalence family. J Vet Intern Med. 2010;24:407-13.

\section{Submit your next manuscript to BioMed Central and we will help you at every step:}

- We accept pre-submission inquiries

- Our selector tool helps you to find the most relevant journal

- We provide round the clock customer support

- Convenient online submission

- Thorough peer review

- Inclusion in PubMed and all major indexing services

- Maximum visibility for your research

Submit your manuscript at www.biomedcentral com/submit
BioMed Central 